\title{
Some Plants Used on Galactogogue from Satpuda Forest Region of Burhanpur District Madhya Pradesh, India
}

\author{
Jafri Z. H. ${ }^{1}$, R. M. Bagul ${ }^{2}$ \\ Post Graduate Research Center in Botany, Dept. of Botany, MGSM's Arts, Science \& Com. College, Chopda.- 425107.India
}

\begin{abstract}
The present paper deals with the traditional ethnoveternary medicinal plants species used for galactogogue by Pawara, Barela \& Bhil tribes. 10 plant species of 10 genera belonging to 10 families with their local name, botanical name, family, and plant part used, preparation of remedies, disease treated, and doses recorded are given.
\end{abstract}

Keywords: Ethnoveternary, Satpuda, Burhanpur, Madhya Pradesh

\section{Introduction}

Burhanpur forest area of Satpuda forest falls in northern part of Burhanpur district .It is situated between $21^{\circ} 18^{\prime}$ and $76^{\circ} 14^{\prime}$ North latitude $\& 21.3^{\circ}$ and $76.23^{\circ}$ East longitude. The vegetation composed of humid \& many semi-evergreen species apart from dry deciduous ones. Tribal's are the Inhabitants of the area with the several tribes like Pawara; Barela \& Bhills.Traditionally medicinal plants are much in use. Studies on the medicinal plants of the area are lacking except few sporadic references. However in India \& Madhya Pradesh significant research work in the field of ethnobotany had been found to carried out by Jain, S.K.1963 [17], 1999[18]; Maheshwari, J.K.1966 [24], 1989[25]; Rai, B.K.Ayachi, S.S [27], Rai. R.Nath.V, Shukla, PK, 1996, 2002[28], 2003[29]; Rai.R 2004; Rai. R.Nath.V, Shukla, PK, 2004a, b, c [30-34]; Saxena, H.O.1988 [36]; Mini V and Sivdasan M 2007[26]; Rahman, et-al 2009[39]; Satya V and Solanki Cm 2009[35]; Yadav D 2009[40]; Similarly studies on Satpura forest from various regions had been carried out by Karnik, C.R.1935[20], Karnik, CR. \& Basu, BD. 1935[19] Karnik, C.R. 1961[21]. Mahabale, TS. \& Karnik, CR.1959 [23] Anonymous, 1994[1]. Ayensu, ES. 1981[2]. Bagul, R.M. and Yadav, S.S. 2003a \& b [3], [4]. Bagul, R.M. and Yadav, S.S. and Garud, B.D. 2006[5]. Bagul, R.M. and Yadav, S.S. 2007[6]. Bagul, R.M. \& D.K. Patil. 2011. Bagul, R.M.2011 [7]. Bagul, RM. 2013[9]. R.M.Bagul, (2015) [11], $[8]$

As far as studies on ethnoveternary medicinal plants of Burhanpur district concern there are no reports so far. Attempt has been made to collect information about ethnoveternary medicinal plants from tribal's of the area [14], [16],[22]. Present study is based on field survey of personal discussion with local village health practitioners (LVHP), \& literature survey from, June 2012-2014.

\section{Materials and Methods}

Extensive \& intensive explorations were made on every Sunday and Saturday of the week end to collect all the information as far as possible regarding the medicinal uses. During outgoing all the information collected were noted in field book. Pertinent attention was paid to habit, habitat, parts used, and diseases for which plants used, dosages and mode of administration. As far as possible correct local names have been recorded. These information were confirmed with repeated queries at different places.

Specimens collected during the field work are processed for herbarium as per the customary methods (Jain and Rao, 1977) [13], S.S Katewa et-al, 2010[37]. Specimens are thoroughly studied for correct identification with the help of the standard Flora of the Presidency of Bombay (Cook, 1958 Repr.ed.)[10], Flora of British India (1872-1897) [12], BSI Flora of Maharashtra state Vol, I, II, \& III.(Edited by Sharma et al.1996,Singh and Kartikeyan 2000;Singh \& Laksh 2001)[15],[38].The identification was also confirmed by matching the specimens with that of authentically identified species at BSI Pune.Herbarium sheets were neatly labeled and deposited in herbarium of PGRC,department of botany arts, Science \& Commerce college Chopda.

\section{1) ANJAN}

\section{Hardwickia binata Roxb. CAESALPINIACEAE}

Trees, with dark-grey, rough-bark. Leaflets sessile obliquely ovate, glabrous. Flowers yellowish-green, in long slender racemes; or terminal panicles. Pods strap shaped.

Distribution: Common in patches in forest, ZHJ 20, Asirgarh.

Threat Status: Vulnerable

Medicinal Uses: Lactation in Cattles: Daily feed of one basket of Leaves $500 \mathrm{~g}-1 \mathrm{~kg}$ are very useful in improving milk production in cattles.

\section{2) BABHUL}

Acacia nilotica (L.) Willd.ex Del subsp. indica (Bth), Brenan MIMOSACEAE

Tall, straight, or crooked trees, with longitudinally fissured bark. Leaves pinnae 4-8 pairs, minute, linear-oblong, jointed. Seeds brownish-black, smooth glabrous.

Distribution: Throughout in plains Burhanpur forest, ZHJ 21, Asirgarh,

Threat Status: Not Endangered

Medicinal Uses: $1 \mathrm{~kg}$.of Immature pods mixed with fodder $\&$ given after delivery in cows to increase milk formation in cows.

\section{Volume 4 Issue 11, November 2015}




\section{International Journal of Science and Research (IJSR) \\ ISSN (Online): 2319-7064 \\ Index Copernicus Value (2013): 6.14 | Impact Factor (2014): 5.611}

Critical Note: Herbal medicines prepared from the tree are useful in throat, cough, diabetes and urino-genital diseases (Salunkhe, 1995).

\section{3) BHUIKUDA/BHUI KOLA}

Pueraria tuberosa (Roxb.ex willd.) DC. FABACEAE

Extensive twinner, silky-grey-pubescent. Leaflets broadly ovate, appressed-hairy. Flowers bluish purple, in long panicles, terminal or from axils of fallen Leaves. Pods 1-6 jointed, brownish-tomentose. Seeds reddish-brown, ellipticoblong, glabrous smooth.

Distribution: Rare in forest, ZHJ 29, Asirgarh,

Threat Status: Endangered

Medicinal Uses: Suppression of lactation: Dried roots powdered. $50 \mathrm{gm}$ powder is given with honey orally .Any problems related with lactation of cows \& bufellows can be treated with root powder and honey which is taken daily twice for a week.

Critical Note: It is very effective medicine for the treatment of female Sterility and given in the condition when women fail to conceive. (Salunkhe, 1995).

\section{4) BOR}

\section{Ziziphus mauritiana Lam. RHAMNACEAE}

Armed, scandent shrubs. Leaves broadly elliptic or ovate oblong, glabrous above. Panicles terminal. Flowers paleyellow or greenish-yellow. Drupes globose, pyriform, whitish green, when ripe.

Distribution: Occasional. ZHJ 110, Asirgarh,

Threat Status: Vulnerable

Medicinal Uses: $100 \mathrm{~g}$ ammonium chloride, $2 \mathrm{~kg}$ sugar and $100 \mathrm{~g}$ of clay is mixed with wheat husk and water is added and kept in an earthen pot up to three days and $750 \mathrm{ml}$ of this mixture is given orally to the animal once in a day to increase lactation

2. $500 \mathrm{~g}$ of dried root powder mixed with cold water \& given orally to increase milk in camels \& Goats. Fruits are edible and digestive.

Critical Note: Vaghbhatta in $600 \mathrm{BC}$ prescribed the bark for heart disease. In modern drugs also it is considered to be best and effective medicine for ischemic heart diseases and to control high blood pressure (VHAI, 1998).

\section{5) CHIRCHITA}

\section{Digera muricata (L) mart. AMARANTHACEAE}

Annual erect, slender herbs. Leaves ovate-lanceolate or elliptic, at times nearly orbicular, glabrous. Seeds pale brown.

Distribution: Throughout common on wastelands, ZHJ 145, Asirgarh,

Threat Status: Not Threatened

Medicinal Uses: Juice extracted from the whole plant is given daily in the morning for 7 days. To increase lactation in cows.

Critical Note: Whole plant is useful on Snake bite, Piles Wounds (R.M. Bagul 2003)

\section{6) GULVEL}

Tinospora cordifolia (Willd.) Mrers ex.Hk.f. \& Th. MENISPERMACEAE

Extensive, deciduous twiners, bark grayish white, lenticillate, grooved. Leaves membranous, broadly ovate-triangular, glabrous, 5-7 veined, petiolate. Racemes, axillary or more commonly from leafless branches. Drupes globose, deep-red, marked with a sub-basal style scar.

Distribution: Throughout on hedges, ZHJ 95, Asirgarh,

Threat Status: Not Endangered

Medicinal Uses: 100-200 g of roots fed with fodder twice a day for five days to increase milking in buffellows

Critical Note

1. Cough: One teaspoonful decoction of roots is given daily three times.

2. Jaundice: For jaundice $50 \mathrm{gm}$ powder of roots is given daily twice with warm water till cured. (R.M. Bagul 2003)

Critical Notes: Chopra et al. (1955) reported anti viral and anti bacterial properties. Gupta et al. year reported its use in diabetes because of its use in insulin secretion and also glucose up take by pancreas.

\section{7) SATAVARI}

Asparagus racemosus Willd.Var.Javanicus (Kunth) Baker LILIACEAE

Deciduous shrubs, with ash brown to pale bark. Cladodes long glabrous. Flowers white in long racemes. Berries nearly globose scarlet or pale purple.

Distribution: Wild in forest undergrowth, ZHJ 20, Asirgarh, Threat Status: Not Endangered

Medicinal Uses: $1-5 \mathrm{~kg}$ of Whole plants is fed to buffellow with empty stomach to increase milk secretion

Critical Note: 1. Roots are useful in stomach complaints and in diarrhea (Sinha \& Sinha, 2001). It is reported for increasing breast milk in mothers (Bhakuni, 1990) reported that the plant has property of uterine blocking.

2. Ash of the whole plant is useful in Stomach Pain \& whole plant is used on eye disease \& impotency (R.M. Bagul 2003)

\section{8). Mangifera indica L. ANACARDIACEAE}

Tall evergreen trees, with light-black longitudinally fissured bark. Leaves alternate, flowers small numerous in long terminal panicles. Drupes yellow to reddish-yellow when ripe.

Distribution: Throughout, ZHJ 20, Asirgarh,.

Threat Status: Cultivated but Vulnerable in wild.

Medicinal Uses: A mixture of $200 \mathrm{~g}$ of dried bark powder, $1 \mathrm{~kg}$ of barley fruits \& $1 \mathrm{~kg}$ of Jaggery is made into 5 liter of water, it is boiled for 30 minutes \& get cooled to given orally two times a day to increase secretion of milk in cows $\&$ goats Water

Critical Note: Vomiting: One teaspoonful extract of young leaves and honey is given twice in prevention of vomiting. (R.M. Bagul 2003)

\section{9) Corchorus capsularis L. TILIACEAE}

Tall erect glabrous herb. Leaves ovate lanceolate, glabrous. Flowers yellow, axillary. Capsule green, Black on drying, Seeds deep brown

Distribution: Subgregaceous range

Threat Status: Cultivated but Vulnerable in wild.

Medicinal Uses: Leaves are fed to Camel to treat stomache. Whole plant 1-2-kg chopped into small pieces and mixed with fodder given to animal with water to increase the secretion of milk. 


\section{International Journal of Science and Research (IJSR) \\ ISSN (Online): 2319-7064}

Index Copernicus Value (2013): 6.14 | Impact Factor (2014): 5.611

10) Legenaria siceraria (Mol) Standl. CUCURBITACEAE A stout climbing, trailing herb. Leaves 3-5 lobed, ovate pubescent, flowers $3-5 \mathrm{~cm}$ across, white axillary solitary. Berries light dark green, seeds white

Distribution: On hedges in Satpuda forest

Threat Status: Cultivated but Vulnerable in wild, ZHJ 20, Asirgarh,

\section{Medicinal Uses:}

1) $3-5 \mathrm{~kg}$ of Fresh fruits chopped into pieces \& given with fodder to increase the secretion of milk.

2) Leaves are fed to camel to treat stomache. A whole plant crushed with water is given to animal to increase the secretion of milk.

Critical Note: Fruits are used as tonic for heart patients (R.M. Bagul 2003)

\section{Discussion and Conclusion}

During study it was found that out of 150 plants species 10 types of plants species used on galactogogue, at the same time 16 types of diseases belonging to 10 families, 10 genera $\& 10$ species used to cure diseases like Headache, Leprosy leucoderma. Lumbergo Snake bite, Piles, Wounds, Acidity, Heart disease, Female sterility, Cough, Jaundice, Eye disease, Stomache, pain etc in human beings [3.4]\&[41] are mentioned with critical notes.

Most of the information reported from the tribal's of the area is found to be less known to the literature of Indian veterinary medicinal plants. The plants mentioned here are still popular in this area and enjoyed good reputation in traditional medicines used on veterinary diseases. Most of the drugs are utilized in fresh mode and as a cooled decoctions or infusions with fodder. It is necessary to make further investigations on these ethnomedicines for conservation of biodiversity to protect extinction of the ethnoveternary medicinal plants .There is also need to brought these plants under cultivation in a systematic manner to meet demands from traditional drug based market

It is also needed to evaluate pharmacologically the efficiency of these plants against ethnoveternary claim.

\section{References}

[1] Anonymous, "Ethnobotany in India A status report", Ministry of Environment and Forests, Govt. of India, 1994.

[2] E.S. Ayensu., Medicinal plants of West Indies, reference publication Inc, Algonac, Michigan, USA, 1981.

[3] R.M.Bagul and S.S.Yadav, "Tribal Medicine for Jaundice from East Khandesh, Satpuda", Geobios, 30, pp.295-296,2003a.

[4] R.M. Bagul and S.S. Yadav, "Antivenomouse Traditional Medicine from Satpuda, East Khandesh", Plant Archives, 3(2), pp.319-320,2003b.

[5] R.M.Bagul, S.S.Yadav and B.D. Garud, "Medicinal Plants of East Khandesh Satpuda with Reference to Their Threat Status and Uses", Plant Archives, 6(1), pp.357-358, 2006.

[6] R.M. Bagul and S.S. Yadav, "Threat Assessment of Some Medicinal Important Plants of Satpuda Forest East Khandesh: A Conservative Approach", Plant Archives, 7(1), pp.367-370, 2007.
[7] R.M.Bagul, "Ecofriendly Food and Vegetable Plants from Satpuda Forest region of East Khandesh, Plant Archives", 11(1), pp.337-338, 2011.

[8] R.M.Bagul and D.K Patil, "Traditional Medicines and healthcare system of tribal's of Shirpur Tehshil of Satpuda Forest. Plant Archives", 11(1), pp.271-273, 2011

[9] R.M. Bagul, "Traditional Medicines and Healthcare Systems of Tribal's of Satpuda forest region of east Khandesh", World J Pharma Res, 1(1), pp.06-09, 2013.

[10] Th. Cook (Repr.ed.), Flora of the Presidency of Bombay Vol. I, II \& III. Bot. Survey of India, Calcutta, 1958

[11]R.M.Bagul, "Traditional Ethnoveternary Practices, Medicinal Plants from Satpuda Forest, East Khandesh, Maharashtra, India”, IJSR,Vol.4,Issue 5, May2015, pp2714-2720, 2015,

[12] J.D.Hooker, The Flora of British India, Vol. I-VII, Reeve and Co.Ltd.London, 1872-1897.

[13] S.K Jain and R.R. Rao, A Handbook of Field \& Herbarium Methods Today \& Tomorrow Printers \& Pub, New Delhi, 1977.

[14]A. G. Beloz, "Plant use knowledge of the WinikinaWarao: The Case for Questionnaires in Ethnobotany", Economic Botany, 56(3), pp. 231-241, 2002,

[15]K. Singh and Laksh. B.S.I. Flora of Maharashtra State Vol. I, II, III, 2001

[16]K.C. Tewary "Folklore Claims on Medicines and Treatments from Assam", Bull. Medicinal and Ethno botanical Research-XII, UNESCO, Paris, 1980.

[17] Jain, S.K., “Observations on Ethnobotany of tribal's of M.P.”, Vanyajati 11(4):177-178, 1963.

[18] Jain, S.K., Dictionary of Ethnoveternary Plants, Deep publications, New Delhi, 1999

[19] Karnik, CR. \& Basu, BD. Indian medicinal plants, Calcutta, 1935.

[20]Karnik, CK., "A Contribution of the biogeographically studies of Khandesh with special reference to Satpuda range". Bombay Georg. Mag, 1:65-72, 1935.

[21]Karnik, C.R.,Studies on the flora and vegetation of Satpuras, Bombay State (India), with a note on the Satpura Mountains, Indian forester, 62:173-183, 1961.

[22] Khare, CP., Encyclopedia of Indian Medicinal plants, Springer, Germany, pp376, 2004.

[23] Mahabale, TS. \& Karnik, CR,'Ecology of Satpura forest, India. Jour. Univ. Poona", 16:61-73, 1959.

[24] Maheshwari, J.K..,Case Study of three primitive tribes of Madhya Pradesh of Central India, Methods and Approaches in Central India, Society of Etthnobotanist, Luchnow, 187-188,1989.

[25] Maheshwari, J.K., "Ethanobotanical documentation of primitive tribes of Madhya Pradesh", J.Econ.Taxon.Bot.Additional series 12:206-213, 1996.

[26] Mani V and Sivdasn M, "Plants used in Ethnoveternary medicine by Kurichya Tribes of Wayanad district in Kerala India, Ethnobotany" 19:94-99, 2007

[27]Rai, B.K., Ayachi, S.S., Rai.A. "A note on Etnomedicines from Central India.”, J.Econ.Taxon.Bot. Additional series 12:186-191, 1996.

[28] Rai, B.K. Nath V, Shukla P.K., "Ethnomedicinal studies of Bhartiya Tribes of Satpura plateau of Madhya Pradesh". Agriculturist, 13(1\&2):109-191, 2002. 


\section{International Journal of Science and Research (IJSR) \\ ISSN (Online): 2319-7064}

Index Copernicus Value (2013): 6.14 | Impact Factor (2014): 5.611

[29] Rai, B.K. Nath V, ShuklaP.K."Ethnobiology of Hill Korwa Tribes Chhattisgarh", Journal of Tropical Forestry, SFRI, and Jabalpur 19(1\&2): 35-46., 2003

[30] Rai, B.K., Madhya Pradesh ke Adivasika van aushadhi ka Prayog, Arnyotsav: 1920, 2004

[31] Rai, B.K. Nath V, ShuklaP.K,'Ethnobotanical studies in Patalkot Valley in Chhindwara district of Madhya Pradesh". Journal of Tropical Forestry, SFRI, Jabalpur 20(2):38, 2004 (a).

[32]Rai, B.K. Nath V,ShuklaP.K., ,Characteristics and Ethnobotanical studies on Primitive tribes of Madhya Pradesh,2004 (b).

[33] Rai, B.K. Nath V, ShuklaP.K. In Govils (edited) recent progress in Medicinal plants Chapter Ethno-medicine and Pharmacognocy. New Delhi: Research Book Center, pp: 8(37)543-552, 2004(C).

[34] Rai, B.K. Nath V, ShuklaP.K, "Ethnobiological studies on Bhartiya tribes of Madhya Pradesh", J. of Tropical Forestry 20(1):150-160, 2004(d).

[35] Satya V and Solanki C.M. "Indigenous knowledge of veterinary medicines among tribes of West Nimar, Madhya Pradesh", Indian J. Trad.Knowledge, 33:896902, 2009.

[36] Saxena H.O., Observation on ethno botany of Madhya Pradesh, bull,Bot.Survey of India, 28:149-156, 1983.

[37] S.S Katewa, P.K Galav,Anita Jain ,Traditional folk veterinary medicines, scientific Publication Udaipur (raj) India , pp 98,194,182,2010.

[38] Singh \& Kathikey, Singh \& Laksh, B.S.I., Flora of Maharashtra State Vol. I, II, III. 2000 \& 2001.

[39] Rahman, C.H. Ghosh A. and Mandal S, "Studies on Ethnoveternary Medicinal Plants used by the Tribes of Birbhum district, West Bengal.” Indian J.Trad.Knowledge.64, 5:368-372., 2009

[40] Yadav D., "Ethnoveternary plants from tribes in habited localities of Ratlam district Madhya Pradesh", India. Indian J. Trad.Knowledge, 33:64-67, 2009

[41] I. B Salunkhe,., Contribution to the flora and vegetation studies of Southern Satpuda ranges with reference to Yawal wild-life Sanctuary. Ph.D. thesis, Univ. of Poona, 1995.

\section{Author Profile}

Zahid Hasan Jafri is M.Sc \& M.Phil in Botany with first Class \& working for $\mathrm{PhD}$ in Botany under the guidance of Dr. R.M.Bagul from Post Graduate Research Center in Botany, MGSMs Arts, Science \& Com. College Chopda Dist. Jalgaon affiliated to North Maharashtra Universiity Jalgaon, Maharashtra, India. I am very much thankful to Principal \& My guide for providing research facilities \& good cooperation for my research work

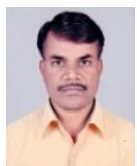

Dr. R. M. Bagul received M.Sc Botany with first Class \& $\mathrm{PhD}$ in Botany from North Maharashtra Universiity Jalgaon, Maharashtra India. Presently working as Head of Botany Department \& P.G.Research Center in Botany at MGSMs Arts, Science \& Com College Chopda, District. Jalgaon of Maharashtra State of India. I have 21 years of teaching \& 15 years of research experience. My thrust areas of research are Plant Taxonomy, Phytosociology, Biodiversity and Conservation, Ethno-Medico botany, Traditional medicines, Pharmacognosy, Plant Reproductive Biology. I am Recognized research guide for M.Phil \& PhD form my university \& Presently 04 students are working for $\mathrm{PhD}$ under my supervision. Published 15 research papers in International peer reviewed Journals \& presented 25 research papers at national \& international level Conferences/Symposia/Seminars. Honored as Fellow of Indian Botanical Society, Jodhpur. Identified as Environmental Expert by Ministry of Forest\& Environment, Govt. of India. Member of BCUD North Maharashtra University Jalgaon from last five years. I am 46 years old. 